1 Implementation and extended evaluation of the Euroimmun Anti-

2 SARS-CoV-2 IgG assay and its contribution to the United Kingdom's

3 COVID-19 public health response.

4

5 Ashley David Otter ${ }^{1,2 *}$, Abbie Bown ${ }^{1}$, Silvia D’Arcangelo ${ }^{1,2}$, Daniel Bailey ${ }^{1}$, Amanda

6 Semper $^{3}$, Jacqueline Hewson ${ }^{2}$, Matthew Catton ${ }^{1}$, Prem Perumal ${ }^{1}$, Angela Sweed ${ }^{1}$,

7 Jessica Jones ${ }^{3}$, Heli Harvala ${ }^{4}$, Abigail Lamikanra ${ }^{4}$, Maria Zambon ${ }^{5}$, Nick Andrews ${ }^{5}$,

8 Heather Whitaker ${ }^{5}$, Ezra Linley ${ }^{6}$, Alexander J Mentzer ${ }^{7,8}$, Donal Skelly8,9,10, Julian C.

9 Knight $^{7}$, Paul Klenerman ${ }^{9}$, PHE Porton Euroimmun testing group ${ }^{11 \dagger}$, Gayatri

10 Amirthalingam ${ }^{5}$, Stephen Taylor ${ }^{12}$, Cathy Rowe ${ }^{11,2}$, Richard Vipond ${ }^{1,3}$, Tim Brooks*3.

12 * - corresponding authors: ashley.otter@phe.gov.uk, tim.brooks@phe.gov.uk

$\dagger$ - Complete list of authors listed in the appendix 1

1 - Diagnostic Support, National Infection Service, Public Health England, Porton, SP4 0JG

2 - SARS-CoV-2 serosurveillance laboratory, National Infection Service, Public Health England, Porton, SP4 OJG

3 - Rare and Imported Pathogens Laboratory, Public Health England, Porton, SP4 0JG

4 - NHS Blood and Transfusion, Microbiology Services, Colindale, UK

5 - Public Health England, Colindale, NW9 5EQ

6 - Seroepidemiology Unit, Public Health England, Manchester, M13 9WZ

7 - Wellcome Centre for Human Genetics, University of Oxford, Oxford, UK

228 -Oxford University Hospitals NHS Foundation Trust, Oxford, UK

239 - Peter Medawar Building for Pathogen Research, Nuffield Department of Medicine, University of Oxford, UK

2410 - Nuffield Department of Clinical Neurosciences, University of Oxford, Oxford, UK

2511 - National Infection Service, Public Health England, Porton, SP4 0JG

2612 - Pathogen Immunology, Public Health England, Porton, SP4 OJG 
medRxiv preprint doi: https://doi.org/10.1101/2021.10.26.21265497; this version posted October 28,2021 . The copyright holder for this preprint (which was not certified by peer review) is the author/funder, who has granted medRxiv a license to display the preprint in It is made available under a CC-BY-NC-ND 4.0 International license .

28 In March 2020, the Rare and Imported Pathogens Laboratory at Public Health 29 England, Porton Down, was tasked by the Department of Health and Social Care with setting up a national surveillance laboratory facility to study SARS-CoV-2 antibody

31 responses and population-level sero-surveillance in response to the growing SARS-

32 CoV-2 outbreak. In the following 12 months, the laboratory tested more than 160,000 33 samples, facilitating a wide range of research and informing PHE, DHSC and UK government policy. Here we describe the implementation and use of the Euroimmun anti-SARS-CoV-2 IgG assay and provide an extended evaluation of its performance. We present a markedly improved sensitivity of $91.39 \%$ ( $\geq 14$ days $92.74 \%, \geq 21$ days $93.59 \%$ ) compared to our small-scale early study, and a specificity of $98.56 \%$. In addition, we detail extended characteristics of the Euroimmun assay: intra- and interassay precision, correlation to neutralisation and assay linearity. 
medRxiv preprint doi: https://doi.org/10.1101/2021.10.26.21265497; this version posted October 28,2021 . The copyright holder for this preprint (which was not certified by peer review) is the author/funder, who has granted medRxiv a license to display the preprint in It is made available under a CC-BY-NC-ND 4.0 International license .

41 Since its emergence in Wuhan, Hubei province, China, in late 2019, the novel severe acute respiratory syndrome coronavirus-2 (SARS-CoV-2) has caused a global pandemic of coronavirus 19 disease (COVID-19). A sobering milestone of three million

44 COVID-19 associated deaths globally was reached on April 162021 , with a cumulative total of more than 150 million SARS-CoV-2 infections reported worldwide ${ }^{1}$. The true scale of SARS-CoV-2 infections globally is likely to be much higher with a substantial number of cases of mild or asymptomatic disease being undetected.

The UK's first confirmed case of COVID-19 occurred in a person who had travelled from Hubei province to England on 23 January 2020 and became symptomatic three days later ${ }^{2}$. By the end of February, all four countries of the UK had recorded COVID19 cases and community transmission was established ${ }^{3}$. Case numbers increased significantly in early March 2020, reaching a total of 6650 laboratory confirmed cases on $23 \mathrm{March}^{4}$ when a national lockdown was implemented. At that time,

54 epidemiological modelling estimated that for every hospitalised COVID-19 case in the 55 UK, there were a further 120-124 infected individuals undetected within the wider community 4 .

57 Individual laboratories began to investigate the use of in-house tests and it became 58 apparent that the UK would benefit from a nationwide service to identify the prevalence 59 of SARS-CoV-2 cases, including asymptomatic ones. Identification of these cases 60 would be essential to inform government policy decisions; to further scientific 61 understanding about immune response evolution, longevity and correlation to 62 protection; and to estimate the true extent of the UK population's exposure to SARS63 CoV-2. Additionally, such a service could address related questions such as the 
64 performance of alternative SARS-CoV-2 serology assays. However, this work was

65 complicated by logistical issues including the availability of relevant test kits that were

66 in global demand, and the availability of relevant sample sets to validate new assays.

67 Described here is the extended evaluation of the SARS-CoV-2 Euroimmun IgG assay,

68 in addition to establishment of a sero-surveillance laboratory using this assay for over

6912 months. 
medRxiv preprint doi: https://doi.org/10.1101/2021.10.26.21265497; this version posted October 28,2021 . The copyright holder for this preprint (which was not certified by peer review) is the author/funder, who has granted medRxiv a license to display the preprint in It is made available under a CC-BY-NC-ND 4.0 International license .

71 The Rare and Imported Pathogens Laboratory (RIPL) at PHE Porton Down was tasked

72 by the UK Government's Department for Health and Social Care (DHSC) with

73 providing a SARS-CoV-2 serology service in support of a national serosurveillance

74 programme. Testing on this scale would require the use of commercial CE-marked

75 serology kits to guarantee the volumes of supply required, the possibility for

76 automation and the necessary quality control of production batches, with our initial

77 focus on an IgG specific assay. An initial market assessment identified only three

78 companies with production kits available. Of these three kits, one targeted antibodies

79 (IgG) against the SARS-CoV-2 spike protein S1 domain, one targeted nucleocapsid,

80 and the third detected antibodies to an unspecified SARS-CoV-2 antigen. Whilst there

81 is merit in having assays that target different antigens for the determination of

82 differential antibody responses to SARS-CoV-2 infection, the use of spike was judged

83 to be critical for virus entry to cells and therefore an assay detecting spike protein

84 antibodies seemed the most attractive for initial use. Thus, the Euroimmun assay

85 (targeting the S1 domain) was selected for the urgent operational requirement and to 86 also provide an indication of the immune profile of subjects.

87 The laboratory had available existing Stratec Biomedical Gemini platforms (Launch

88 Diagnostics, UK) capable of performing automated ELISAs. After initial ELISA

89 optimisation on the Gemini platform, the first samples were tested to generate initial

90 verification and evaluation data, using samples obtained from patients early in

91 infection and with limited or incomplete clinical data through collaborators/hospitals. 
medRxiv preprint doi: https://doi.org/10.1101/2021.10.26.21265497; this version posted October 28,2021 . The copyright holder for this

preprint (which was not certified by peer review) is the author/funder, who has granted medRxiv a license to display the preprint in It is made available under a CC-BY-NC-ND 4.0 International license .

93 On the $30^{\text {th }}$ March 2020, PHE Porton Down went live with a COVID-19 serology

94 service for the UK, with an initial capacity of $\sim 800$ samples a day. This was later

95 expanded upon addition of two further Gemini platforms, doubling capacity to $\sim 1,600$

96 samples a day. Just over 12 months later, as of $31^{\text {st }}$ of April 2021, over 160,000

97 samples have been analysed through this assay and workflow, providing answers to

98 key questions about disease spread and the seroprevalence of SARS-CoV-2 infection,

99 as well as informing outbreak management activities. To date, the Euroimmun assay

100 has helped to deliver several significant studies for the UK population, covering

101 population serosurveillance ${ }^{5}$; healthcare worker exposure ${ }^{6}$; selection of donors for

102 convalescent plasma ${ }^{7-10}$; characterisation of reference standards; and research to

103 determine the durability of the immune response $e^{6,11,12}$. 
medRxiv preprint doi: https://doi.org/10.1101/2021.10.26.21265497; this version posted October 28,2021 . The copyright holder for this preprint (which was not certified by peer review) is the author/funder, who has granted medRxiv a license to display the preprint in It is made available under a CC-BY-NC-ND 4.0 International license .

4. Methods

\section{Serum samples}

107 Early samples were sourced from collaborating colleagues at PHE Porton Down, PHE 108 Sero-epidemiology Unit Manchester (SEU) and hospitals across England under 109 Material Transfer Agreements (MTAs). These included residual diagnostic sera from 110 SARS-CoV-2 PCR-confirmed samples from hospital in-patients (Guy's and St 111 Thomas' Hospital, The Royal Free, Barnet Hospital and North Hampshire County 112 Hospital, Basingstoke and John Radcliffe Hospital, Oxford), with data available on 113 dates of collection versus onset of disease. Samples collected in Oxford were from 114 individuals consented into 2 studies: Gastro-intestinal illness in Oxford: COVID 115 substudy [Sheffield REC, reference: $16 / \mathrm{YH} / 0247$ ] and Sepsis Immunomics project 116 [Oxford REC C, reference:19/SC/0296]) as described ${ }^{13}$. The large majority of samples 117 were sourced from community cases of SARS-CoV-2 described within the FF100 ${ }^{14}$ 118 and the PHE serology assay evaluation supporting information ${ }^{15}$. Of the Oxford patient 119 cohort, 116 patients were classified as having mild disease, 15 severe, 13 120 asymptomatic, 6 critical and 1 death.

121 To validate the Euroimmun assay (and future serology assays), pre-pandemic 122 negative samples were also sourced to determine specificity. These were obtained 123 from serum banks prior to the COVID-19 outbreak by the Royal College of General 124 Practitioners (RCGP) for routine surveillance schemes and held by PHE SEU.

\section{Euroimmun anti-SARS-CoV-2 IgG assay}

126 All testing using the Euroimmun anti-SARS-CoV-2 IgG assay (El 2606-9601 G, 127 Euroimmun, Lübeck) was performed using an automated microplate processor 128 (Stratec Gemini), which automates all aspect of the ELISA from sample dilution, Page 7 of 36 
medRxiv preprint doi: https://doi.org/10.1101/2021.10.26.21265497; this version posted October 28,2021 . The copyright holder for this preprint (which was not certified by peer review) is the author/funder, who has granted medRxiv a license to display the preprint in It is made available under a CC-BY-NC-ND 4.0 International license .

129 through to incubations, washing, reading and analysis, according to the

130 manufacturer's instructions for use. Positive and negative kit controls provided by

131 Euroimmun were included with every run, with commercial positive and negative anti-

132 SARS-CoV-2 controls used in parallel (ACCURUN® Anti-SARS-CoV-2 Controls Kit -

133 Series 1000; SeraCare, Gaithersburg) for additional internal quality control. Control

134 values were tracked using a Levy-Jennings plot with Westgard rules applied.

135 The assay is semi-quantitative, with results expressed as a ratio (index) of the 136 extinction (optical density) of the patient sample (or control) over the extinction of the

137 calibrator. Interpretation of samples were defined according to the manufacturer, with

138 an index value of $<0.8$ defined as negative, $>0.8$ to 1.1 defined as 139 indeterminate/borderline and $\geq 1.1$ interpreted as positive.

\section{Linearity and assay variation}

141 To determine the assay linearity, five high titre serum samples were pooled, with two-

142 fold dilutions generated, and each dilution was run in replicates of five. Similarly, the 143 NIBSC Anti-SARS-CoV-2 Antibody Diagnostic Calibrant (20/162, NIBSC, Potters Bar) 144 was run in triplicate across $1: 5,1: 10,1: 20,1: 50$ and $1: 100$ dilutions. Results from both 145 the pool and NIBSC calibrant were used to determine the linearity of the Euroimmun 146 assay.

147 The pooled serum samples were additionally used to determine the intra- and inter148 assay variation, with five replicates measured each day across five days.

\section{Microneutralisation against SARS-CoV-2}

150 On a panel of 138 convalescent blood donors that were $>28$ days post-symptom onset, 151 micro-neutralisation titres against SARS-CoV-2 were determined as previously 152 described ${ }^{7}$, with neutralisation titres compared against Euroimmun ratio results. 
medRxiv preprint doi: https://doi.org/10.1101/2021.10.26.21265497; this version posted October 28, 2021. The copyright holder for this preprint (which was not certified by peer review) is the author/funder, who has granted medRxiv a license to display the preprint in It is made available under a CC-BY-NC-ND 4.0 International license .

\section{Extended verification of the Euroimmun assay}

154 In our original small-scale evaluation of the Euroimmun assay, reported in June $2020^{16}$ and derived from samples obtained early in the outbreak, 100 PCR-positives samples

where the time between sampling and symptom onset was known, were used to determine assay sensitivity, whilst 399 pre-pandemic negatives, 50 serum samples

158 from 2015 seronegative for Borrelia burgdorferi and 50 confounder samples (VZV,

159 EBV, CMV and rheumatoid positive) were used to determine specificity (left panel on

160 Figure 1). Of the positive panel, 100 samples were initially used but this was later reduced to 93, as seven were found to not be PCR-confirmed. Of the positive samples, $67 / 93$ tested positive ( $\geq 1.1$ ratio) on the Euroimmun assay, giving an overall sensitivity of $72.0 \%(95 \% \mathrm{Cl} 61.78-80.86)$ (Table 1, Figure 3, PHE Original). When analysing only samples taken $\geq 14$ days post-symptom onset, the sensitivity was $73.42 \%(95 \% \mathrm{Cl}$ $62.28-82.73)$ and at $\geq 21$ days, the sensitivity was $74.67 \%(95 \% \mathrm{Cl} 63.30-84.01)^{16}$.

Subsequent to our initial establishment of the serosurveillance service using the

167 Euroimmun assay, further commercial immunoassay platforms and kits were 168 evaluated at the request of the DHSC to inform decisions on the use of high-throughput assays by NHS laboratories for the detection of anti-SARS-CoV-2 antibodies in patient samples $^{13,17}$. As part of this work, we extended our evaluation of the Euroimmun assay. Due to the limited samples and volumes available for the evaluation of high-

172 throughput serology platforms, the panels differed slightly between our initial

173 Euroimmun evaluation and subsequent other commercial assay evaluations 174 performed by PHE Porton Down ${ }^{15}$. For the extended evaluation, an additional 592 175 PCR-positive samples that were used for the different verifications of the higher176 throughput platforms (including a head-to-head study ${ }^{13}$ ) were tested using the 177 Euroimmun anti-SARS-CoV-2 IgG assay.

Page 9 of 36 
medRxiv preprint doi: https://doi.org/10.1101/2021.10.26.21265497; this version posted October 28, 2021. The copyright holder for this preprint (which was not certified by peer review) is the author/funder, who has granted medRxiv a license to display the preprint in

It is made available under a CC-BY-NC-ND 4.0 International license .
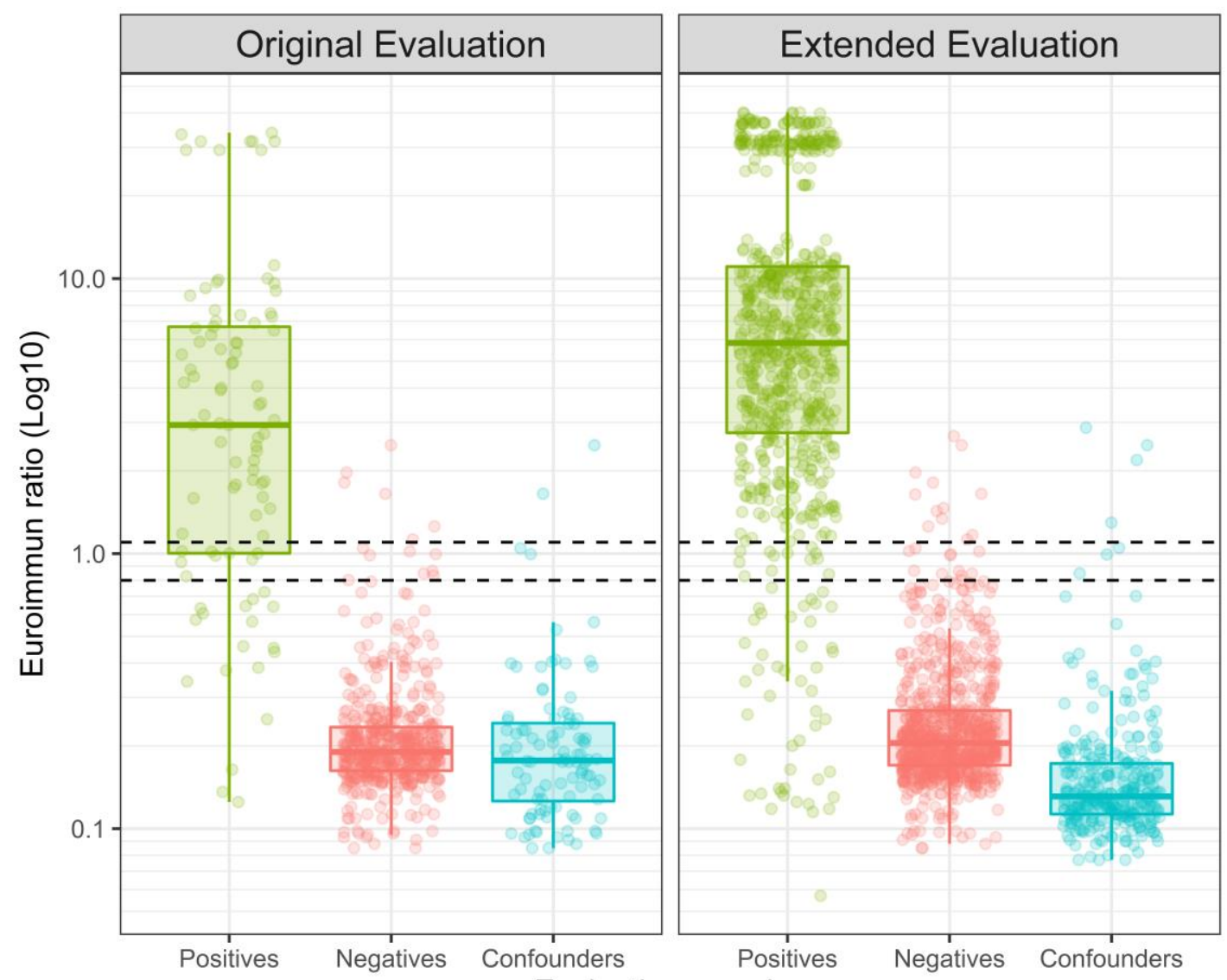

Evaluation samples

179 Figure 1: Distribution of evaluation sample results split according to; Left: Original evaluation 180 ( $n=692)$, and Right: Extended evaluation $(n=1,799)$. Dashed lines represent the 181 indeterminate range of the Euroimmun assay (ratio or index or s/co $\geq 0.8$ and $<1.1$ ). 
medRxiv preprint doi: https://doi.org/10.1101/2021.10.26.21265497; this version posted October 28,2021 . The copyright holder for this preprint (which was not certified by peer review) is the author/funder, who has granted medRxiv a license to display the preprint in It is made available under a CC-BY-NC-ND 4.0 International license .

183 Using this larger panel, the overall sensitivity of the Euroimmun assay was found to 184 be $91.39 \%$ (95\% Cl $89.03 \%$ to $93.38 \%$ ), increasing to $92.74 \%$ when using samples 185 with an onset of $\geq 14$ days ( $95 \% \mathrm{Cl} 90.49 \%$ to $94.60 \%$ ) and $93.59 \%$ when using 186 samples with an onset of $\geq 21$ days ( $95 \% \mathrm{Cl} 91.41 \%$ to $95.36 \%$ ), markedly improved 187 from the original evaluation (Figure 1, Table 1, Figure 3).

188 Additionally, the specificity panel was expanded from 499 to 1,114 samples: 303 189 confounders (CMV, VZV, EBV and Rheumatoid positive samples), 711 pre-pandemic 190 negatives and 100 Lyme disease negative samples from 2015. Using this panel, a 191 specificity of $98.56 \%$ was calculated $(95 \% \mathrm{Cl} 97.65-99.17 \%, n=1,114)$, similar to that 192 from the original evaluation (specificity of $99.0 \%$; $95 \% \mathrm{Cl}, 97.5-99.7 \%$ ).

193 Receiver operating characteristic (ROC) analyses showed the highest area under 194 curve (AUC) value was obtained (0.9902) when using samples from the extended 195 evaluation panel with an interval of $\geq 21$ days from onset of symptoms, whilst the 196 original evaluation showed the lowest AUC (0.9584) (Table 2, Figure 2).

197 When examining the temporal distribution of the samples used for each of these 198 evaluations, there was variation in the interval since disease/symptom onset (Figure 199 3). Initial evaluation samples gave the highest frequency of reactive samples at 28 200 days, whilst the extended evaluation showed the highest interval frequency spanning $20136-43$ days after symptom onset. The majority of convalescent samples with intervals 202 of $<21$ days tested positive ( 25 out of 53 samples).

203 This variation in interval distribution is reflected by the difference in the sensitivities 204 seen between the two evaluations. Figure 3 clearly shows that many of the initial PHE 205 evaluation samples was limited in interval range, in part by sample availability, with 206 samples typically taken between 14 to 35 days after symptom onset. This may account 
medRxiv preprint doi: https://doi.org/10.1101/2021.10.26.21265497; this version posted October $28,2021$. The copyright holder for this

preprint (which was not certified by peer review) is the author/funder, who has granted medRxiv a license to display the preprint in It is made available under a CC-BY-NC-ND 4.0 International license .

207 for differences in sensitivities with some samples potentially taken too soon after onset

208 of symptoms to identify any detectable antibody response. Conversely, many of the

209 extended evaluation samples, by their nature, were taken from convalescent patients

210 who had had sufficient interval post onset to generate a strong antibody response.

211 However, it should also be noted that no normalisation for sample demographics (for

212 example differences in geographic location, gender, ethnicity or patient age-ranges)

213 had been applied between datasets, so may have occurred and contributed to

214 differences in sensitivity. Analysis of influence of demographic factors between sample

215 sets is beyond the scope of this overview but may be reported in more detail in

216 individual studies. None of our evaluation sets included longitudinal samples from the

217 same patient. 
medRxiv preprint doi: https://doi.org/10.1101/2021.10.26.21265497; this version posted October 28, 2021. The copyright holder for this preprint (which was not certified by peer review) is the author/funder, who has granted medRxiv a license to display the preprint in It is made available under a CC-BY-NC-ND 4.0 International license .

218 Table 1: Sensitivity of the Euroimmun assay from the original PHE evaluation and the 219 extended evaluation described here. Samples giving an indeterminate value are included with 220 negative results.

\begin{tabular}{|c|c|c|c|c|c|c|c|c|c|}
\hline & \multicolumn{3}{|c|}{ All samples } & \multicolumn{3}{c|}{ Samples $>14$ days } & \multicolumn{3}{c|}{ Samples $>21$ days } \\
\hline Panel & $\mathrm{n}$ & $\begin{array}{c}\text { sensitivity } \\
(\%)\end{array}$ & $95 \% \mathrm{Cl}$ & $\mathrm{n}$ & $\begin{array}{c}\text { sensitivity } \\
(\%)\end{array}$ & $95 \% \mathrm{Cl}$ & $\mathrm{n}$ & $\begin{array}{c}\text { sensitivity } \\
(\%)\end{array}$ & $95 \% \mathrm{Cl}$ \\
\hline Original $^{16}$ & 93 & 72.00 & $\begin{array}{c}61.78 \% \\
\text { to } \\
80.86 \%\end{array}$ & 83 & 73.42 & $\begin{array}{c}62.28 \% \\
\text { to } \\
82.73 \%\end{array}$ & 77 & 74.67 & $\begin{array}{c}63.30 \% \\
\text { to } \\
84.01 \%\end{array}$ \\
\hline Extended & 685 & 91.39 & $\begin{array}{c}89.03 \% \\
\text { to } \\
93.38 \%\end{array}$ & 600 & 92.74 & $\begin{array}{c}90.49 \% \\
\text { to } \\
94.60 \%\end{array}$ & 579 & 93.59 & $\begin{array}{c}91.41 \% \\
\text { to } \\
95.36 \%\end{array}$ \\
\hline
\end{tabular}

221

222 Table 2: ROC analysis values for each of the evaluation panels, with the extended evaluation 223 described here split by total and intervals of $\geq 14$ and $\geq 21$ days.

\begin{tabular}{|l|c|c|c|c|c|c|}
\hline Evaluation & Panel & Area & $\mathrm{P}$ value & $95 \% \mathrm{Cl}$ & $\begin{array}{c}\text { Negatives (incl. } \\
\text { confounders) }\end{array}$ & Positives \\
\hline Original $^{16}$ & Total & 0.9584 & $<0.0001$ & 0.9266 to 0.9902 & 499 & 93 \\
\hline \multirow{3}{*}{ Extended } & Total & 0.9729 & $<0.0001$ & 0.9631 to 0.9827 & 1114 & 685 \\
\cline { 2 - 7 } & $\geq 14$ days & 0.9886 & $<0.0001$ & 0.9826 to 0.9946 & 1114 & 600 \\
\cline { 2 - 7 } & $\geq 21$ days & 0.9902 & $<0.0001$ & 0.9846 to 0.9958 & 1114 & 579 \\
\hline
\end{tabular}

224

225

226 
medRxiv preprint doi: https://doi.org/10.1101/2021.10.26.21265497; this version posted October 28, 2021. The copyright holder for this preprint (which was not certified by peer review) is the author/funder, who has granted medRxiv a license to display the preprint in

It is made available under a CC-BY-NC-ND 4.0 International license .

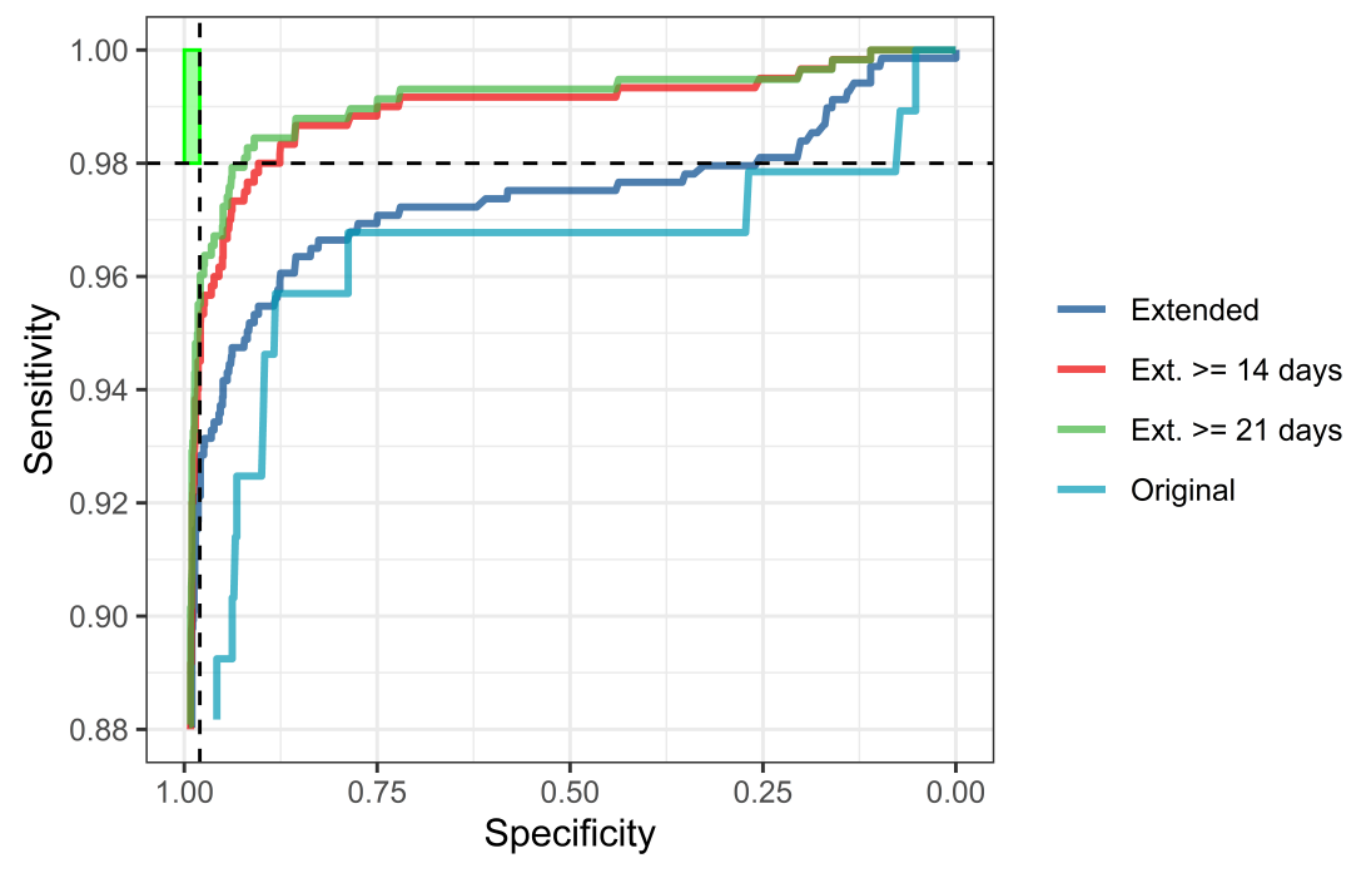

228 Figure 2: ROC curves for the Euroimmun assay. Curves are shown for the original ( $n=592)$ 229 and extended evaluations $(n=1,799)$, with the extended evaluation further split to show 230 samples with intervals of $\geq 14(n=1,714)$ or $\geq 21$ days $(n=1,693)$ after symptom onset. The 231 green box indicates the MHRA Target Product Profile of serology assays (>98\% sensitivity 232 and specificity) at $>20$ days. 
medRxiv preprint doi: https://doi.org/10.1101/2021.10.26.21265497; this version posted October 28, 2021. The copyright holder for this preprint (which was not certified by peer review) is the author/funder, who has granted medRxiv a license to display the preprint in

It is made available under a CC-BY-NC-ND 4.0 International license.

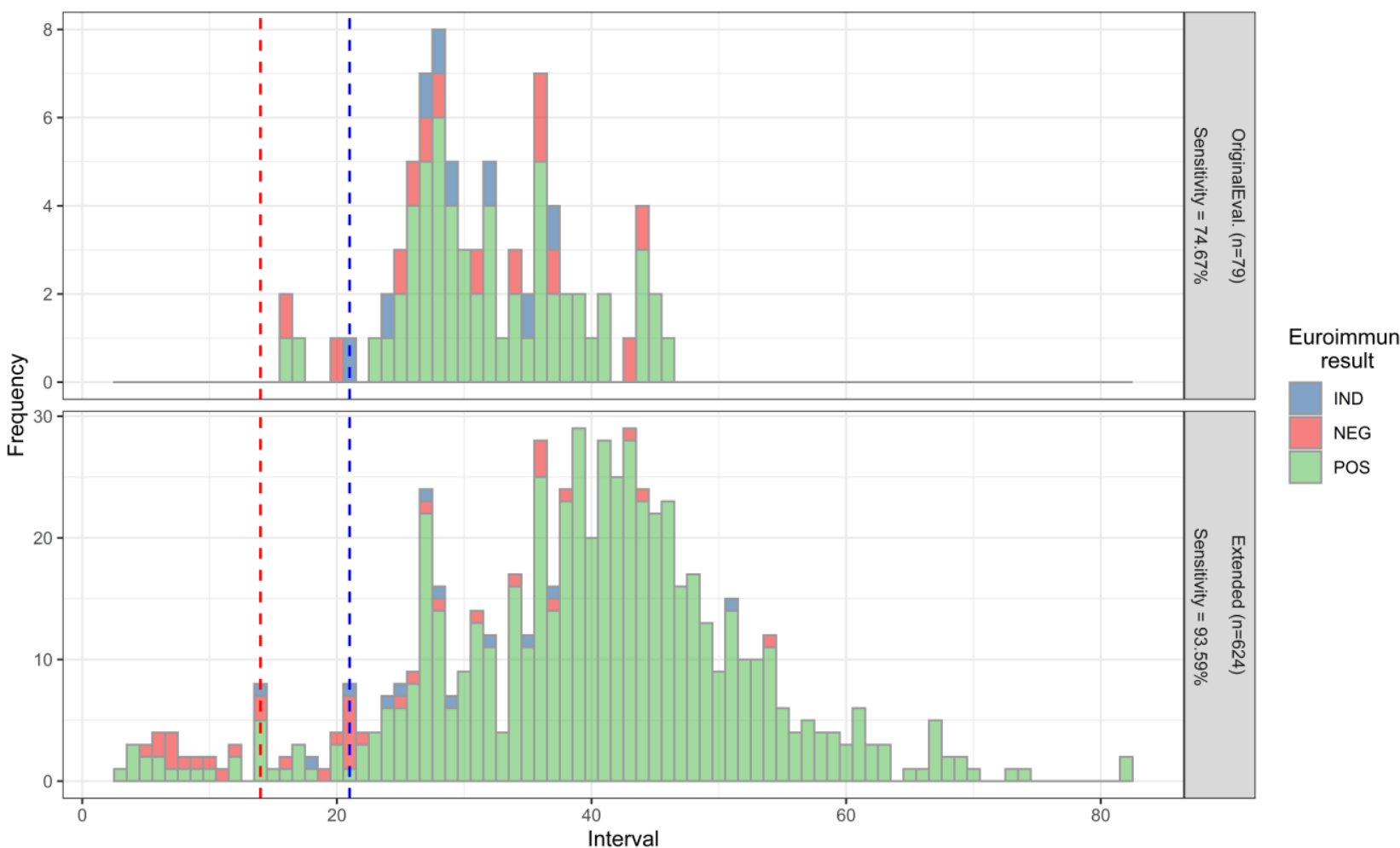

234 Figure 3: An overview of samples by interval distribution and evaluation panel, coloured by 235 the Euroimmun assay result. Top: Original evaluation $(n=79)$. Bottom: Extended evaluation 236 (n=624). The sensitivity at an interval of $\geq 21$ days is included in each graph, in line with the 237 MHRA TPP. Red dashed line indicates 14-day interval, blue dashed line indicates 21-day 238 interval. 
medRxiv preprint doi: https://doi.org/10.1101/2021.10.26.21265497; this version posted October 28,2021 . The copyright holder for this preprint (which was not certified by peer review) is the author/funder, who has granted medRxiv a license to display the preprint in It is made available under a CC-BY-NC-ND 4.0 International license .

\section{Further assay characteristics}

241 To determine the precision of the Euroimmun assay, five pooled patient samples were 242 used in the absence of an international standard or calibrant at the time to generate a 243 dilution series for linearity and to determine inter- and intra-assay variation, testing five 244 replicates each over five days. The intra-assay and inter-assay variations were found 245 to be $<7 \%$ and $<5 \%$ covariance (CV), respectively, indicating high precision when 246 comparing samples across multiple days and replicate samples (Table S1).

247 Similarly, the dilution series was used to determine the linear range of the assay, with 248 an $\mathrm{R}^{2}$ value of 0.985 (Figure 4). As more standards became available, the NIBSC 249 Anti-SARS-CoV-2 Antibody Diagnostic Calibrant was serially diluted to generate 250 additional linearity data, providing a similar $R^{2}$ value of 0.955 (Figure 4). From the 251 pooled patient sera and the NIBSC calibrant dilutions, the linear range of the assay 252 was determined to lie between index values of 1 and 9 . It is noted that the reader 253 configuration on the Gemini platform resulted in strong positive samples that saturated 254 the OD reader and the software assigns an over-read OD value (e.g. 9.999), which 255 can result in an index value of between $25-38$ depending on the calibrator OD 256 reading. In routine use, the assay was used in a qualitative mode (e.g. 257 positive/negative interpretation respectively) so saturating values were appropriately 258 assigned as positive.

259 Serology assays that have a strong correlation to neutralising antibody titres are useful 260 surrogates for live virus neutralisation assays, which require significant containment 261 level 3 work. Of the 138 samples that were tested by both neutralisation and the 262 Euroimmun assay, 129 were positive on both, whilst nine were only positive by 263 Euroimmun (Figure 5), with seven of these samples giving an index result of $1-2$ 
medRxiv preprint doi: https://doi.org/10.1101/2021.10.26.21265497; this version posted October 28, 2021. The copyright holder for this preprint (which was not certified by peer review) is the author/funder, who has granted medRxiv a license to display the preprint in It is made available under a CC-BY-NC-ND 4.0 International license .

264 (close to the indeterminate range). There was a strong correlation between the 265 Euroimmun results and the neutralisation titre, with an $R$ of $0.83\left(R^{2}=0.69\right)$. 
medRxiv preprint doi: https://doi.org/10.1101/2021.10.26.21265497; this version posted October 28, 2021. The copyright holder for this preprint (which was not certified by peer review) is the author/funder, who has granted medRxiv a license to display the preprint in

It is made available under a CC-BY-NC-ND 4.0 International license .

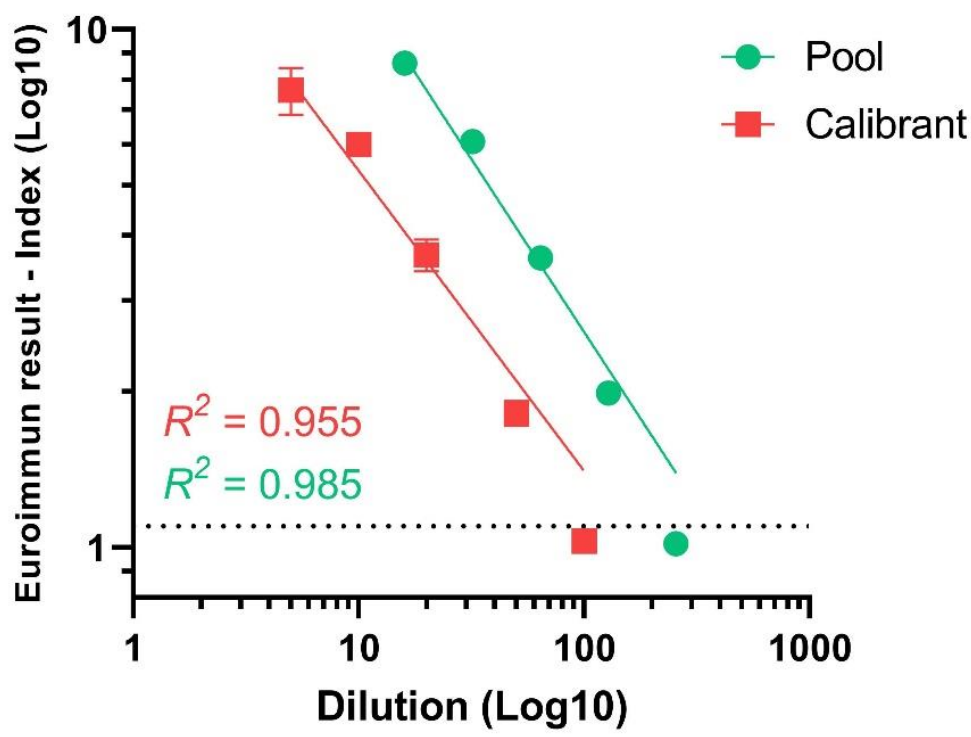

268 Figure 4: Dilutions and linear range of the Euroimmun assay, using pooled patient samples 269 (pool; green) and the 20/162 NIBSC Anti-SARS-CoV-2 Antibody Diagnostic Calibrant 270 (calibrant; red). Results $>9$ were removed due to saturated OD readings. Results with an index 271 of $\geq 1.1$ are considered positive whilst those $<0.8$ are considered negative, with the 272 indeterminate range (0.8 to 1.1) shown with the dashed black line. 
medRxiv preprint doi: https://doi.org/10.1101/2021.10.26.21265497; this version posted October 28, 2021. The copyright holder for this preprint (which was not certified by peer review) is the author/funder, who has granted medRxiv a license to display the preprint in

It is made available under a CC-BY-NC-ND 4.0 International license.

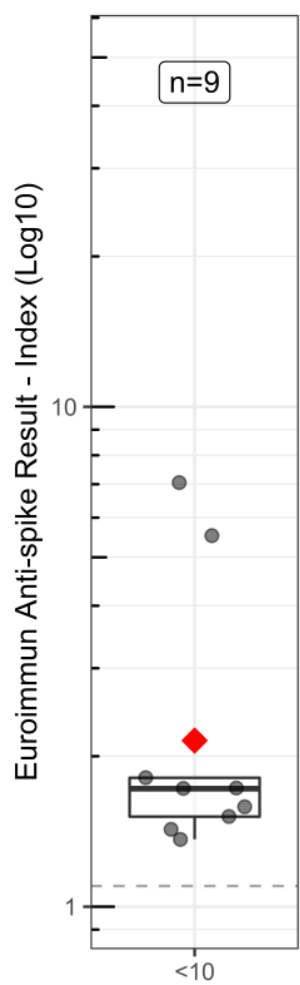

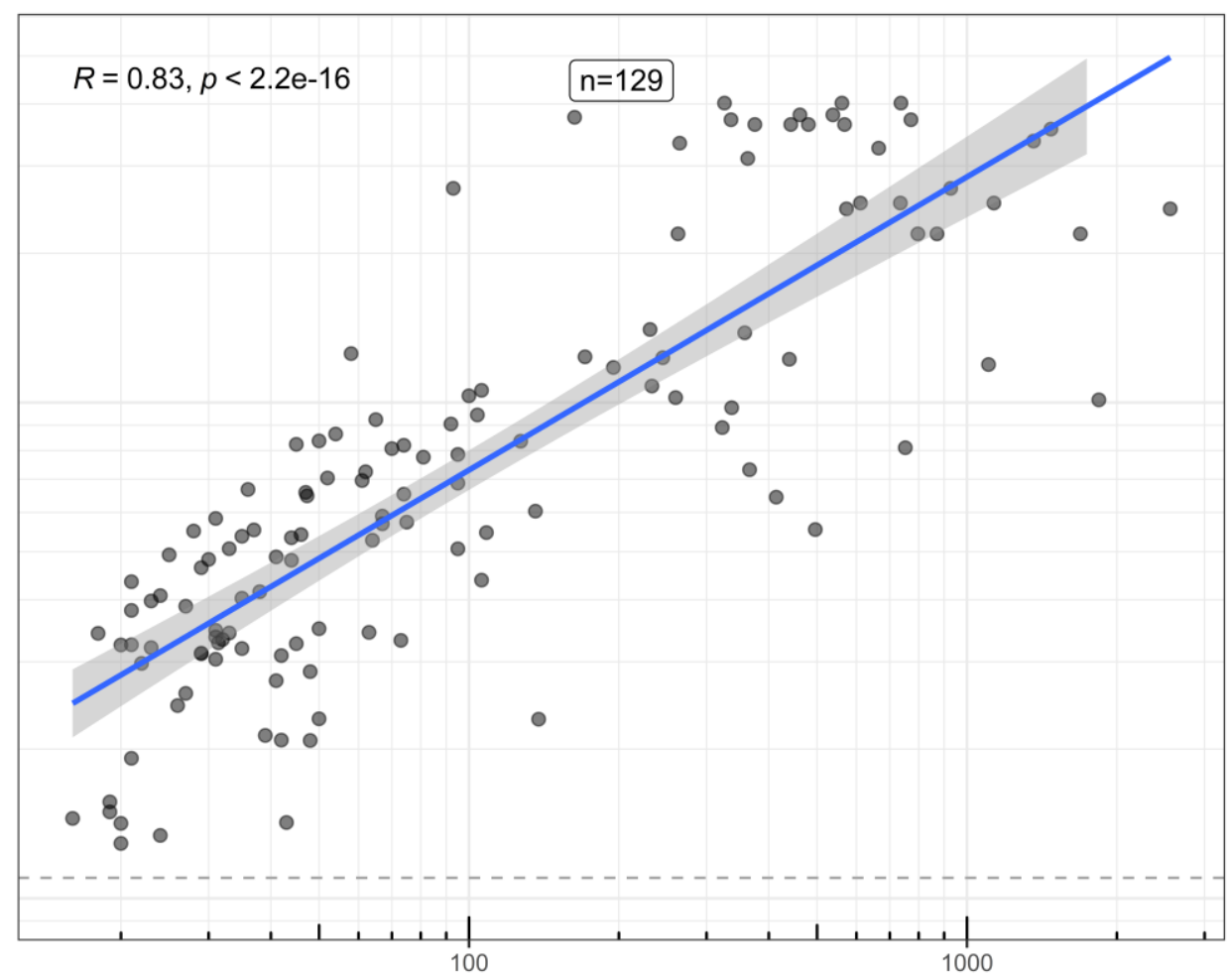

Virus neutralisation antibody titre (Log10)

Figure 5: Comparison of convalescent blood donor serum samples tested using the Euroimmun anti-SARS-CoV-2 IgG assay (Log 10 ratio value) and virus neutralisation antibody titre (Log10). Good correlation $\left(R=0.83, R^{2}=0.69\right)$ was observed between neutralisation and the Euroimmun assay. Blue line indicates linear model, with $95 \%$ confidence interval (grey range). Dashed line indicates the positive cut-off value ( $\geq 1.1$ index), whilst the red square shows the mean of the samples negative by neutralisation, but positive by Euroimmun assay. 
medRxiv preprint doi: https://doi.org/10.1101/2021.10.26.21265497; this version posted October 28, 2021. The copyright holder for this preprint (which was not certified by peer review) is the author/funder, who has granted medRxiv a license to display the preprint in It is made available under a CC-BY-NC-ND 4.0 International license .

283 A number of national and local projects with appropriate ethical approvals have been 284 facilitated through this work and Figure 6 indicates the scope of Euroimmun testing performed by PHE Porton Down between March 2020 to April 2021. Descriptions of some of these projects are highlighted below although more comprehensive analysis

287 is published elsewhere from the respective project groups.

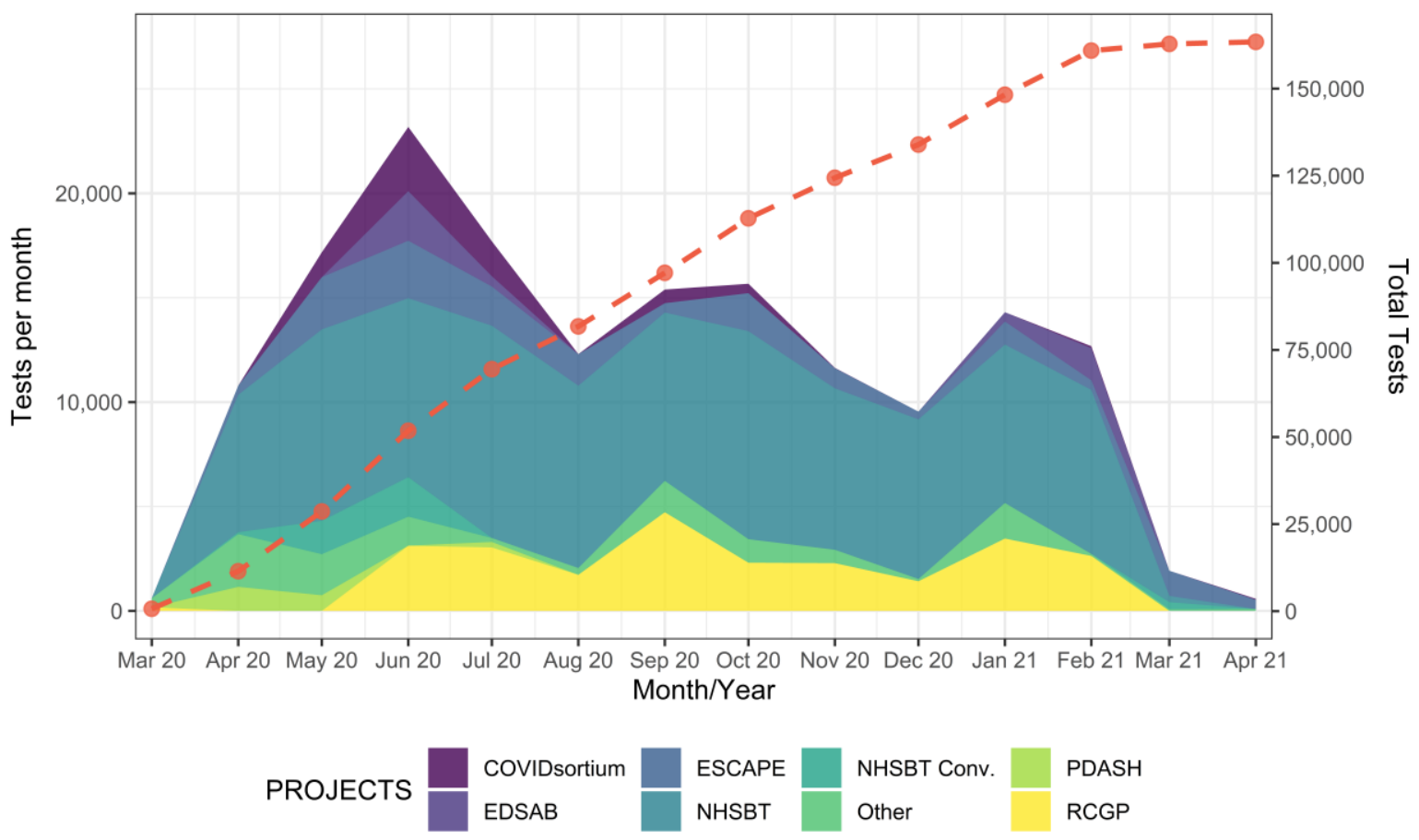

Figure 6: An overview of the number of samples tested using the Euroimmun assay at PHE 290 Porton Down, with total tests (red-dashed line), spanning March 2020 to April 2021. Colours 291 indicate different projects, as described in the text. Projects have since been moved to 292 additional platforms as of March 2021.

294 As part of a UK serosurveillance scheme, anonymised residual blood donor samples 295 from people aged 17-84 from different regions of England were sourced from the NHS 296 Blood and Transplant (NHSBT) service to provide additional venous blood samples to 297 determine COVID-19 seroprevalence by age and region. This data began prior to other 
medRxiv preprint doi: https://doi.org/10.1101/2021.10.26.21265497; this version posted October 28,2021 . The copyright holder for this preprint (which was not certified by peer review) is the author/funder, who has granted medRxiv a license to display the preprint in It is made available under a CC-BY-NC-ND 4.0 International license .

serosurveillance studies (for example, REACT, ONS) so provided PHE and external modelling groups with the only source of seroprevalence data for the UK at the time. Approximately 10,000 samples were tested monthly and positivity rate on the

301 Euroimmun assay was determined on a weekly basis, to identify the population-level spread of COVID-19 and inform government decision-making. Data was reported to the Public Health England seroepidemiology steering group, scientific pandemic influenza group on modelling (SPI-M) and DHSC, as well as published in the weekly PHE COVID-19 report ${ }^{5}$. This data helped to determine and understand the scale of asymptomatic spread of COVID-19 within the UK population, allowing PHE, DHSC and modellers to assess age groups and areas that are driving transmission.

In addition to the NHSBT serosurveillance, blood samples were obtained from patients visiting primary care settings via the Royal College of General Practitioners (RCGP)

310 Research and Surveillance Centre to determine COVID-19 seroprevalence, with a 311 total of 24,927 samples tested since March 2020.

312 As part of a collaboration between PHE and NHSBT, convalescent plasma donor 313 samples were tested to determine which donations should be provided for clinical trials 314 assessing the therapeutic effects of convalescent plasma treatment of patients with 315 COVID-19 (NHSBT Conv). The Euroimmun assay was chosen as the results showed a good correlation with neutralisation assays ${ }^{7,8}$; and donations with a Euroimmun 317 serology index result of $>9.1$ (later revised to 6.0 ) were shown to be associated with 318 the presence of high neutralising antibody titres of $1: 100$ or higher ${ }^{7,8}$ and were hence 319 selected for trial use. Serological testing in support of this project began in April 2020, 320 with the first patients receiving treatment in the beginning of May as part of the REMAP-CAP trial ${ }^{10}$ and subsequently via the RECOVERY trial ${ }^{9}$. 
medRxiv preprint doi: https://doi.org/10.1101/2021.10.26.21265497; this version posted October 28,2021 . The copyright holder for this preprint (which was not certified by peer review) is the author/funder, who has granted medRxiv a license to display the preprint in It is made available under a CC-BY-NC-ND 4.0 International license .

322 Whilst laboratory antibody testing using ELISAs is considered the gold-standard for

323 determining population-level exposure to SARS-CoV-2, additional studies were 324 conducted to determine the feasibility of using lateral flow device antibody tests. On 325 request from DHSC, a study was performed on emergency service workers to evaluate 326 the utility of home antibody testing kits; EDSAB-HOME (Evaluating Detection of 327 SARS-CoV-2 AntiBodies at HOME). Capillary blood samples from $>2,500$ volunteers 328 were tested on different lateral flow devices and a contemporaneous venous sample 329 was tested on the Euroimmun assay as the reference test ${ }^{18}$.

330 From the start of the first COVID-19 lockdown in the UK (23 March 2020), the 331 COVIDsortium study (NCT04318314) collected serial samples from a cohort of 731 332 healthcare workers $(\mathrm{HCW})$ with the aim of identifying host and pathogen correlates of 333 protection and pathogenesis in mild/asymptomatic SARS-CoV-2 infection ${ }^{19,20}$. The 334 Euroimmun assay was used throughout to characterise the serostatus of all study 335 samples which by completion of the final follow-up samples at 1 year, will number 336 more than 13,000 samples. This data helped to define the proportion of this HCW 337 cohort who seroconverted, and was used to monitor the longitudinal antibody 338 response and rate of decline of anti-S1 $\lg$ antibodies ${ }^{6}$ and to investigate the 339 relationship between peak anti-S1 IgG titre and neutralising antibody titre ${ }^{21}$.

340 In addition, a small project (ESCAPE) began in March 2020 as a mechanism to study 341 antibody responses to infection. A cohort of Public Health England staff across 4 sites 342 were recruited, with monthly blood donations taken as a way to understand the kinetics 343 of antibodies post-infection ${ }^{11}$.

344 A collaboration between PHE and Hampshire Hospitals NHS Foundation Trust 345 (HHFT), provided 1885 serial samples from 282 hospital in-patients with acute COVID- 
34619 and 189 serial samples from 50 convalescent HCWs (the PDASH study). All

347 participants had PCR confirmed SARS-CoV-2 infections that ranged from

348 asymptomatic to severe disease. The study used the Euroimmun assay to determine

349 the time to seroconversion and to monitor the longitudinal antibody response in study

350 participants.

351 Other projects included those used specifically for serology assay evaluations 352 conducted by PHE Porton and PHE SEU, smaller research studies, and those 353 conducted by hospitals and colleagues early in the pandemic. 
medRxiv preprint doi: https://doi.org/10.1101/2021.10.26.21265497; this version posted October 28,2021 . The copyright holder for this preprint (which was not certified by peer review) is the author/funder, who has granted medRxiv a license to display the preprint in It is made available under a CC-BY-NC-ND 4.0 International license .

8. Discussion

356 The Euroimmun assay has been fundamental to the UK's public health response to

357 COVID-19, with >160,000 samples tested March 2020 to March 2021 (Figure 6). This

early availability of the assay was key to performing seroprevalence testing in the early stages of the pandemic, informing the policy and legislative responses of PHE, DHSC and the UK Government. It also contributed to our understanding of immune responses during COVID-19 infection and recovery as well as provided real-time ( 24 hours) testing of convalescent plasma before being provided for use in clinical trials.

Whilst many platforms and assays now exist for the detection of anti-SARS-CoV-2 364 antibodies (including those evaluated by ourselves ${ }^{22}$ ), there were limited choices 365 available at the onset of the pandemic in the UK in March 2020. This highlights the need and basis for pandemic preparedness from an immunology and serology perspective, with the requirement for labs to be able to run high-throughput antibody tests on specimens from patients infected with newly emerging pathogens. Rapid 369 immunology research on a new pathogen enables early understanding of potential 370 immunity and inform early vaccine design. Whilst in-house/research-based assays were available since January 2020, these require significant quality control to ensure consistent diagnosis across batches of samples to ensure consistent sensitivity.

373 Similarly, in-house assays can also suffer from logistical and supply issues for 374 specially manufactured components (recombinant proteins etc). Commercial assays 375 became rapidly available with the spread of SARS-CoV-2 in early 2020, however supply and logistical issues were also evident with the global spread of SARS-CoV-2, 377 so this should be a factor in deciding on assays for serosurveillance. 
medRxiv preprint doi: https://doi.org/10.1101/2021.10.26.21265497; this version posted October 28,2021 . The copyright holder for this preprint (which was not certified by peer review) is the author/funder, who has granted medRxiv a license to display the preprint in It is made available under a CC-BY-NC-ND 4.0 International license .

379 In our original evaluation, we found an overall sensitivity of $72.0 \%$ (interval $\geq 14$ days: $38073.42 \%$, interval $\geq 21$ days: $74.67 \%$ ) and a specificity of $99.0 \%$ for the Euroimmun 381 assay, whilst the extended evaluation detailed here found an overall sensitivity of $38291.39 \%$ (interval $\geq 14$ days: $92.74 \%$, interval $\geq 21$ days: $93.59 \%$ ) and a specificity of $38398.56 \%$ (Table 1, Figure 2). This data is supported by other studies, which have 384 shown similar high sensitivities of $90 \%^{23}, 96 \%{ }^{24}$ and $100 \%^{25}$. The initial evaluation suggested a moderate sensitivity for the Euroimmun assay, but this is likely a reflection of the early stages of the pandemic, when serum from patients with confirmed COVID19 were extremely difficult to obtain, disease onset was poorly characterised and little convalescent material was available. This limited the number of samples, as many of the original evaluation samples were obtained from patients with mild disease within the community, so in using these particular samples, this could have resulted in lower sensitivity than anticipated, due to mild infections and resulting in lower antibody 392 responses than those with severe infections or those requiring hospitalisation ${ }^{26}$. In 393 addition, timing between disease onset and sample date was not fully established for 394 all patient samples, with many taken from patients too early since disease onset, whereby no robust $\lg G /$ immunological response is mounted.

Use of an extended sample panel has enabled us to better evaluate the Euroimmun assay. Although the Euroimmun assay showed improved sensitivity in our extended evaluation, in our analysis, it still does not meet the MHRA's Target Product Profile (TPP) of $>98 \%$ sensitivity recommendation for SARS-CoV-2 serology assays to determine if people have recent infection of SARS-CoV- $2^{27}$; it does however meet the TPP of $>98 \%$ specificity.

402 In addition to improved sensitivity using this extended panel, intra- and inter-assay 403 variation was found to be low, with covariance of $<7 \%$ and $<5 \%$, respectively. Using 
medRxiv preprint doi: https://doi.org/10.1101/2021.10.26.21265497; this version posted October 28,2021 . The copyright holder for this preprint (which was not certified by peer review) is the author/funder, who has granted medRxiv a license to display the preprint in It is made available under a CC-BY-NC-ND 4.0 International license .

404 pooled patient samples and the NIBSC diagnostic calibrant, the linear range of the 405 assay was also determined, enabling semi-quantitative comparisons (Figure 4). Our 406 results are consistent with other studies that show that only a defined range of the 407 Euroimmun assay can be used to reliably infer a linear range ${ }^{6}$.

408 As an anti-spike (S1 domain) antibody ELISA, the Euroimmun assay results also 409 correlate with neutralising antibody titres $\left(R=0.83, R^{2}=0.69\right)$ as shown elsewhere ${ }^{7,8,28}$, 410 suggesting that this assay provides a useful surrogate for virus neutralisation and 411 possible correlation to immune protection (Figure 5), without the requirement for 412 containment level 3 facilities and live-virus culture. However, other pseudo-type 413 assays have shown higher correlation ${ }^{28}$, likely due to the different dynamics between 414 antibody-binding assays and neutralisation-based assays.

415 In addition, as an indirect sandwich ELISA, results are only semi-quantitative and 416 display a maximum reading for optical densities due to reader saturation. In our 417 equipment implementation depending on the calibrator value, max OD values can then 418 result in an index value of between approximately 26 and 38, preventing direct 419 comparisons between samples unless the calibrator values are similar or are within 420 the linear range of the assay, determined here to be between OD values of 1 and 9 , 421 (Figure 4). If quantitative results are desired, our recommendation is to dilute samples 422 that are strongly positive to within this range.

423 Notably, of the serology assays evaluated by PHE Porton Down to date ${ }^{22}$, the 424 Euroimmun assay format does not require the installation of dedicated 425 machinery/specialist equipment, similar to other plate-based ELISA assays. This 426 enables wider use of the assay: it can be utilised in most laboratory settings using 427 automated pipetting platforms (such as the Stratec Gemini), or on the bench with 
medRxiv preprint doi: https://doi.org/10.1101/2021.10.26.21265497; this version posted October 28, 2021. The copyright holder for this preprint (which was not certified by peer review) is the author/funder, who has granted medRxiv a license to display the preprint in It is made available under a CC-BY-NC-ND 4.0 International license.

428 manual pipetting, or within the field since only limited additional laboratory equipment

429 such as a plate reader is required.

430 Serology assay selection for different requirements is complex ${ }^{29}$. This initial 431 programme was principally focused on serosurveillance, further work is now underway 432 at PHE Porton to determine antibody responses induced by vaccination ${ }^{30}$, vaccine 433 effectiveness ${ }^{31}$, vaccine coverage, variant infection and population spread ${ }^{32}$, using a 434 combination of serology assays targeting different antigens. With additional assays 435 now available, we have expanded our assays to encompass those with improved 436 sensitivity and specificity, with the capability to change rapidly, enabling better and 437 more accurate analysis of the differing and refined responses to the SARS-CoV-2. 438 Newer assays have enabled us to determine specific protein sub-domain responses 439 (e.g. anti-RBD), as well as using a combination of assays as a mechanism to 440 differentiate between those with previous infection (presence of both anti-spike and 441 anti-nucleocapsid antibodies), those with vaccination and no previous infection 442 (presence of only anti-spike antibodies) and those with previous infection and 443 vaccination (presence of both anti-spike and anti-nucleocapsid antibodies, with 444 significantly higher anti-spike responses as reported elsewhere ${ }^{30}$ ). 
medRxiv preprint doi: https://doi.org/10.1101/2021.10.26.21265497; this version posted October 28, 2021. The copyright holder for this preprint (which was not certified by peer review) is the author/funder, who has granted medRxiv a license to display the preprint in It is made available under a CC-BY-NC-ND 4.0 International license .

\section{Acknowledgements and funding}

446 We thank the many scientists and clinicians that provided PHE Porton with early

447 samples from those with PCR-confirmed SARS-CoV-2 infection in March 2020,

448 including those at Guy's and St Thomas' Hospital, Westminster, Royal Free Hospital,

449 Barnet and North Hampshire County Hospital, Basingstoke. In addition, we thank

450 collaborators from the head-to-head study at Oxford University (Gillian Rodger, 451 Hayleah Pickford, Teresa Street, Kate Dingle, Justine Rudkin, Derrick Crook, David 452 Eyre, Philippa Matthews and Nicole Stoesser).

453 This project was funded as part of the DHSC serological assay evaluation procedure.

454 AJM and DTS are funded by ISARIC-4C "Medical Research Council (grant 455 MC_PC_19059) as part of the ISARIC Coronavirus Clinical Characterisation 456 Consortium (ISARIC-4C)", COMBAT Consortium, OUH clinical and research staff and 457 patients

\section{Author contributions}

459 ADO and AB wrote the manuscript. AB, DB, ADO, SD'A, TB, AS, MC, PP, AS and RV performed and oversaw the initial evaluation and assay implementation. ADO, AB and SD'A performed the extended assay characterisation. AB, ST, JH, CR and SD'A were responsible for routine testing. EL provided initial evaluation samples and EL \& AS 463 facilitated with sourcing samples. AJM and DTS provided additional evaluation samples. $\mathrm{AL}, \mathrm{HH}$ and $\mathrm{MZ}$ were responsible for the microneutralisation work. All authors read and commented on the final manuscript. 
medRxiv preprint doi: https://doi.org/10.1101/2021.10.26.21265497; this version posted October $28,2021$. The copyright holder for this preprint (which was not certified by peer review) is the author/funder, who has granted medRxiv a license to display the preprint in It is made available under a CC-BY-NC-ND 4.0 International license .

468 11. References

469 1. World Health Organization. COVID-19 Weekly Epidemiological Update 22. $470 \quad$ World Heal. Organ. 1-3 (2021).

4712 2. Lillie, P. J. et al. Novel coronavirus disease (Covid-19): The first two patients in 472 the UK with person to person transmission. Journal of Infection 80, 578-606 473 (2020).

474 3. Chappell, J. G. et al. Retrospective screening of routine respiratory samples revealed undetected community transmission and missed intervention opportunities for SARS-CoV-2 in the United Kingdom. medRxiv 2020.08.18.20174623 (2020). doi:10.1101/2020.08.18.20174623

478 4. Public Health England. National COVID-19 surveillance reports. (2020).

479 5. Public Health England. Public Health England National flu and COVID-19 480 surveillance reports.

481

6. Manisty, C. et al. Time series analysis and mechanistic modelling of 482 heterogeneity and sero-reversion in antibody responses to mild SARS-CoV-2 483 infection. EBioMedicine 65, 103259 (2021).

484 7. Harvala, H. et al. Convalescent plasma therapy for the treatment of patients with COVID-19: Assessment of methods available for antibody detection and their correlation with neutralising antibody levels. Transfus. Med. 1-9 (2020). doi:10.1111/tme.12746

8. Harvala, H. et al. Convalescent plasma treatment for SARS-CoV-2 infection: analysis of the first 436 donors in England, 22 April to 12 May 2020. Eurosurveillance 25, 2001260 (2020). 
medRxiv preprint doi: https://doi.org/10.1101/2021.10.26.21265497; this version posted October 28, 2021. The copyright holder for this preprint (which was not certified by peer review) is the author/funder, who has granted medRxiv a license to display the preprint in It is made available under a CC-BY-NC-ND 4.0 International license .

491 9. RECOVERY Collaborative Group. Convalescent plasma in patients admitted to 492 hospital with COVID-19 (RECOVERY): a randomised controlled, open-label, platform trial. Lancet (2021). doi:10.1016/S0140-6736(21)00897-7

494 495

496

497

498

499

500

501

502

503

504

505

506

507

508

509

510

511

512 17. Public Health England. Evaluation of sensitivity and specificity of four 513

10. REMAP-CAP Investigators, Estcourt, L. J. Convalescent Plasma in Critically ill Patients with Covid-19. medRxiv 2021.06.11.21258760 (2021).

11. Harris, R. J. et al. Serological surveillance of SARS-CoV-2: Six-month trends and antibody response in a cohort of public health workers. J. Infect. 1-25 (2021). doi:10.1016/j.jinf.2021.03.015

12. Amirthalingam, G. et al. Seroprevalence of SARS-CoV-2 among Blood Donors and Changes after Introduction of Public Health and Social Measures, London, UK. Emerg. Infect. Dis. 27, 1795-1801 (2021).

13. Ainsworth, M. et al. Performance characteristics of five immunoassays for SARS-CoV-2: a head-to-head benchmark comparison. Lancet Infect. Dis. 20, 1390-1400 (2020).

14. Boddington, N. L. et al. COVID-19 in Great Britain: Epidemiological and clinical characteristics of the first few hundred (FF100) cases: A descriptive case series and case control analysis. medRxiv (2020). doi:10.1101/2020.05.18.20086157

15. Public Health England. Supporting information for the PHE commercial serology assay evaluations.

16. Public Health England. Evaluation of the Euroimmun Anti-SARS-CoV-2 ELISA (IgG) serology assay for the detection of anti-SARS-CoV-2 antibodies. (2020). commercially available SARS-CoV-2 antibody immunoassays. (2020). 
medRxiv preprint doi: https://doi.org/10.1101/2021.10.26.21265497; this version posted October 28, 2021. The copyright holder for this preprint (which was not certified by peer review) is the author/funder, who has granted medRxiv a license to display the preprint in It is made available under a CC-BY-NC-ND 4.0 International license .

514 18. Mulchandani, R. et al. Accuracy of UK Rapid Test Consortium (UK-RTC) 'abC19 Rapid Test' for detection of previous SARS-CoV-2 infection in key workers: Test accuracy study. BMJ 371, (2020).

19. Moon, J. C. et al. Healthcare Workers Bioresource: Study outline and baseline characteristics of a prospective healthcare worker cohort to study immune protection and pathogenesis in COVID-19. Wellcome Open Res. 5, (2020).

20. Treibel, T. A. et al. COVID-19: PCR screening of asymptomatic health-care workers at London hospital. The Lancet 395, 1608-1610 (2020).

21. Reynolds, C. J. et al. Discordant neutralizing antibody and T cell responses in asymptomatic and mild SARS-CoV-2 infection. Sci. Immunol. 5, (2020).

22. Public Health England. COVID-19: laboratory evaluations of serological assays. GOV.UK (2021). Available at: https://www.gov.uk/government/publications/covid-19-laboratory-evaluationsof-serological-assays. (Accessed: 2nd June 2021)

23. Lassaunière, $\mathrm{R}$. et at. al. Evaluation of nine commercial SARS-CoV-2 immunoassays. medRxiv 2020.04.09.20056325 (2020). doi:10.1101/2020.04.09.20056325

24. GeurtsvanKessel, C. H. et al. An evaluation of COVID-19 serological assays informs future diagnostics and exposure assessment. Nat. Commun. 11, (2020).

25. Manalac, J. et al. Evaluation of Abbott anti-SARS-CoV-2 CMIA IgG and 690 (2020).

536 26. Rijkers, G. et al. Differences in antibody kinetics and functionality between 
medRxiv preprint doi: https://doi.org/10.1101/2021.10.26.21265497; this version posted October $28,2021$. The copyright holder for this preprint (which was not certified by peer review) is the author/funder, who has granted medRxiv a license to display the preprint in It is made available under a CC-BY-NC-ND 4.0 International license.

severe and mild severe acute respiratory syndrome Coronavirus 2 infections. J. Infect. Dis. 222, 1265-1269 (2020).

539

540

541

542

543

544

545

546

547

548

549

550

551

552

553

554

555

556

557

558

559

27. MHRA. Target Product Profile: antibody tests to help determine if people have recent infection to SARS-CoV-2: Version 2. Available at: https://www.gov.uk/government/publications/how-tests-and-testing-kits-forcoronavirus-covid-19-work/target-product-profile-antibody-tests-to-helpdetermine-if-people-have-recent-infection-to-sars-cov-2-version-2. (Accessed: 8th April 2021)

28. Lamikanra, A. et al. Comparability of six different immunoassays measuring SARS-CoV-2 antibodies with neutralizing antibody levels in convalescent plasma: From utility to prediction. Transfusion 61, 2837-2843 (2021).

29. Peeling, R. W. et al. Serology testing in the COVID-19 pandemic response. Lancet Infect. Dis. 20, e245-e249 (2020).

30. Manisty, C. et al. Antibody response to first BNT162b2 dose in previously SARSCoV-2-infected individuals. Lancet (2021). doi:10.1016/S0140-6736(21)005018

31. Hall, V. J. et al. COVID-19 vaccine coverage in health-care workers in England and effectiveness of BNT162b2 mRNA vaccine against infection (SIREN): a prospective, multicentre, cohort study. Lancet (London, England) 1725-1735 (2021). doi:10.1016/S0140-6736(21)00790-X

32. Whitaker, H. et al. Impact of COVID-19 Vaccination Program on Seroprevalence in Blood Donors in England, 2021. J. Infect. (2021). doi:10.1016/j.jinf.2021.04.037 
medRxiv preprint doi: https://doi.org/10.1101/2021.10.26.21265497; this version posted October 28, 2021. The copyright holder for this preprint (which was not certified by peer review) is the author/funder, who has granted medRxiv a license to display the preprint in It is made available under a CC-BY-NC-ND 4.0 International license

560

561

562

Page 33 of 36 
medRxiv preprint doi: https://doi.org/10.1101/2021.10.26.21265497; this version posted October 28, 2021. The copyright holder for this preprint (which was not certified by peer review) is the author/funder, who has granted medRxiv a license to display the preprint in It is made available under a CC-BY-NC-ND 4.0 International license .

563 Table S1: Precision results for the Euroimmun assay using five pooled patient sera.

564 Samples were tested in replicates of five over five days. Intra-assay variation was $565<7 \%$, whilst inter-assay variation was $<5 \%$

\begin{tabular}{|c|c|c|c|c|c|c|c|c|c|}
\hline Sample & & $\begin{array}{c}\text { Day } \\
1\end{array}$ & $\begin{array}{c}\text { Day } \\
2\end{array}$ & $\begin{array}{c}\text { Day } \\
3\end{array}$ & $\begin{array}{c}\text { Day } \\
4\end{array}$ & $\begin{array}{c}\text { Day } \\
5\end{array}$ & $\begin{array}{l}\text { Inter- } \\
\text { assay } \\
\text { Mean }\end{array}$ & $\begin{array}{c}\text { Inter- } \\
\text { assay } \\
\text { SD }\end{array}$ & $\begin{array}{l}\text { Inter- } \\
\text { assay } \\
\text { CV }\end{array}$ \\
\hline 1 & Mean & 9.00 & 8.43 & 8.59 & 8.43 & 8.64 & \multirow{3}{*}{8.62} & \multirow{3}{*}{0.235} & \multirow{3}{*}{2.724} \\
\hline & SD & 0.26 & 0.13 & 0.14 & 0.08 & 0.13 & & & \\
\hline & CV & 2.93 & 1.59 & 1.60 & 0.99 & 1.50 & & & \\
\hline 2 & Mean & 6.28 & 5.95 & 5.99 & 6.04 & 6.12 & \multirow{3}{*}{6.08} & \multirow{3}{*}{0.132} & \multirow{3}{*}{2.180} \\
\hline & SD & 0.11 & 0.19 & 0.13 & 0.16 & 0.28 & & & \\
\hline & CV & 1.69 & 3.26 & 2.18 & 2.64 & 4.50 & & & \\
\hline 3 & Mean & 3.72 & 3.52 & 3.55 & 3.67 & 3.67 & \multirow{3}{*}{3.62} & \multirow{3}{*}{0.087} & \multirow{3}{*}{2.409} \\
\hline & SD & 0.11 & 0.12 & 0.04 & 0.19 & 0.11 & & & \\
\hline & CV & 2.84 & 3.52 & 1.13 & 5.17 & 2.93 & & & \\
\hline 4 & Mean & 2.07 & 1.90 & 1.99 & 1.99 & 1.99 & \multirow{3}{*}{1.99} & \multirow{3}{*}{0.062} & \multirow{3}{*}{3.102} \\
\hline & SD & 0.04 & 0.03 & 0.06 & 0.09 & 0.08 & & & \\
\hline & CV & 2.16 & 1.72 & 3.12 & 4.42 & 4.04 & & & \\
\hline 5 & Mean & 1.07 & 0.98 & 1.02 & 0.99 & 1.03 & \multirow{3}{*}{1.02} & \multirow{3}{*}{0.037} & \multirow{3}{*}{3.620} \\
\hline & SD & 0.07 & 0.01 & 0.04 & 0.02 & 0.07 & & & \\
\hline & CV & 6.28 & 0.55 & 3.76 & 2.46 & 6.60 & & & \\
\hline
\end{tabular}

566 
medRxiv preprint doi: https://doi.org/10.1101/2021.10.26.21265497; this version posted October 28, 2021. The copyright holder for this preprint (which was not certified by peer review) is the author/funder, who has granted medRxiv a license to display the preprint in It is made available under a CC-BY-NC-ND 4.0 International license .

568 Table S2: Determination of linear range of Eurolmmun assay using serially

569 diluted pooled patient sera. Pooled serum samples at dilutions of 2, 4 and 8 were

570 removed due to OD saturation.

\begin{tabular}{|l|l|l|l|}
\hline Source & Dilution & Index (mean) & SD \\
\hline Patient pool & 16 & 8.617 & 0.235 \\
\hline & 32 & 6.077 & 0.132 \\
\hline & 64 & 3.624 & 0.087 \\
\hline & 128 & 1.987 & 0.062 \\
\hline Calibrant & 256 & 1.018 & 0.037 \\
\hline & 5 & 7.636 & 0.793 \\
\hline & 10 & 6.000 & 0.279 \\
\hline & 20 & 3.673 & 0.261 \\
\hline & 50 & 1.820 & 0.100 \\
\hline & 100 & 1.029 & 0.045 \\
\hline & 200 & 0.614 & 0.013 \\
\hline & & & \\
\hline & & & \\
\hline & & & \\
\hline & & & \\
\hline & & & \\
\hline & & & \\
\hline & & & \\
\hline & & & \\
\hline & & & \\
\hline & & & \\
\hline
\end{tabular}


medRxiv preprint doi: https://doi.org/10.1101/2021.10.26.21265497; this version posted October 28, 2021. The copyright holder for this preprint (which was not certified by peer review) is the author/funder, who has granted medRxiv a license to display the preprint in It is made available under a CC-BY-NC-ND 4.0 International license .

\section{Appendix 1}

574 PHE Porton Euroimmun testing group list of authors:

575 Joanna Bacon, Daniel Bailey, Natalie Baker, Jack Bleach, Debbie Blick, Paul Bolton,

576 Abbie Bown, Olivia Carr, Matthew Catton, Melanie Clifford, Tom Coleman, Charlie

577 Cooper, Charlotte Cornbill, Ellie Cross, Mollie Curran-French, Silvia D’Arcangelo,

578 Owen Daykin-Pont, Charlotte Dixon, Phoebe Do Carmo Silva, Ellie Drinkwater, Jackie

579 Duggan, Xena Dyball, Jack Easton, Ruth Elderfield, Anaya Ellis, Jenna Furneaux,

580 Harriet Garlant, Barry Gibney, Supriya Gurung, Rachel Halkerston, Robin Hanson,

581 James Hardy, Alexander Hargreaves, Gabrielle Harker, Becky Harrison, Bethany

582 Hicks, Charlotte Hind, Emma Hobbs, James Hogg, Margarita Jablonska, Leah Johal,

583 Caoimhe Kelly, Carensa Knights, Emily Laing, Deborah Lister, Rosa Loffredo, Adam

584 Mabbutt, Bethany Martin, Felicity Marx, Lara Mason, Joanna McGlashan, Debbie

585 McKee, Isobel Miles, Sebastian Millward, Gloria Mongelli, Christopher Moon, Taalia

586 Morgan, Alexandra Morrison, Alexandra Morrison, Anna Moy, Josh Nelthorpe-Cowne,

587 Jack Nevols, Jane Osbourne, Jodie Owen, Ros Packer, Jordan Pascoe, Prem

588 Perumal, Esther Picton-Barlow, Eleanor Porges, Saskia Proud, Deen Qureshi,

589 Anastasia Richardson, April Roberts, Adam Roberts, Amanda Semper, Lauren

590 Setterfield, Jennifer Small, Kirstie Speer, Sara Speight, Angela Sweed, Stephen

591 Taylor, Steve Thomas, Sian Tiley, Elizabeth Truelove, Ann Varghese, Richard Vipond,

592 Rosie Watts, Katie West, Clare Wilson, Kate Withycombe, Charlotte Woolley. 